\title{
Teaching Chemistry Based on the Stimulus Equivalence Model $^{1}$
}

\author{
Marcelo de Abreu César², Melania Moroz ${ }^{2}$ \\ ${ }_{2}^{2}$ Pontifícia Universidade Católica de São Paulo, São Paulo-SP, Brazil
}

\begin{abstract}
This study aimed to verify the effects of a procedure, based on the stimulus equivalence model, to teach naming 10 chemical elements, from their symbolic representations and their respective numbers and atomic models. Eight high school students participated. Four classes of stimuli were used: (A) name; (B) symbol; (C) atomic number; (E) atomic model of chemical elements. The following were performed: evaluation of the initial repertoire; teaching of conditional relations and testing of emergence of new conditional relations; evaluation of the final repertoire. From the teaching of three relations (AB, BC and BE), almost all participants presented at least $90 \%$ of correct answers (hits) in nine relations (BA, CB, AC, CA, EB, AE, EA, CE, EC); in the chemical elements naming (BD, CD and $\mathrm{ED}$ ), seven participants obtained at least $80 \%$ of hits. The efficiency of teaching procedure for chemistry learning at the high school level has been verified.
\end{abstract}

Keywords: high school, chemistry, programmed instruction, behavior analysis, stimulus equivalence

\section{Ensino de Química com Base no Modelo de Equivalência de Estímulos}

Resumo: Este estudo teve por objetivo verificar os efeitos de um procedimento, elaborado com base no modelo de equivalência de estímulos, para ensinar a nomear 10 elementos químicos, a partir de suas representações simbólicas e de seus respectivos números e modelos atômicos. Participaram oito alunos do Ensino Médio. Utilizaram-se quatro classes de estímulos: (A) nome; (B) símbolo; (C) número atômico; (E) modelo atômico dos elementos químicos. Foram realizadas: avaliação do repertório inicial; ensino de relações condicionais e teste de relações emergentes; avaliação do repertório final. A partir do ensino de três relações (AB, $\mathrm{BC}$ e $\mathrm{BE})$, a quase totalidade dos participantes apresentou, no mínimo, 90\% de acertos em nove relações (BA, CB, AC, CA, EB, AE, EA, CE, EC); na nomeação do elemento químico (BD, CD e ED), sete participantes obtiveram, no mínimo, $80 \%$ de acertos. Verificou-se a eficiência da programação de ensino para o aprendizado de química em nível médio.

Palavras-chave: ensino médio, química, instrução programada, análise do comportamento, equivalência de estímulos

\section{Enseñanza de Química basada en el Modelo de Equivalencia de Estímulos}

Resumen: Este estudio tuvo por objetivo verificar los efectos de un procedimiento, elaborado con base en el modelo de equivalencia de estímulos, para enseñar a nombrar 10 elementos químicos, a partir de sus representaciones simbólicas y de sus respectivos números y modelos atómicos. Participaron ocho alumnos de la secundaria. Se utilizaron cuatro clases de estímulos: (A) nombre; (B) símbolo; (C) número atómico; (E) modelo atómico de los elementos químicos. Se realizaron: evaluación del repertorio inicial; enseñanza de relaciones condicional y prueba de relaciones emergentes; evaluación del repertorio final. En la enseñanza de tres relaciones $(\mathrm{AB}$, $\mathrm{BC}$ y $\mathrm{BE}$ ), la casi totalidad de los participantes presentó, como mínimo, el $90 \%$ de aciertos en nueve relaciones (BA, CB, AC, CA, EB, AE, EA, CE, EC); en el nombramiento del elemento químico (BD, CD y ED), siete participantes obtuvieron al menos el $80 \%$ de aciertos. Se verificó la eficiencia de la programación de enseñanza para el aprendizaje de química, a nivel de enseñanza secundaria.

Palabras clave: enseñanza secundaria, química, instrucción programada, análisis del comportamiento, equivalencia de estímulos

Chemistry, part of the Natural Sciences, is present in culture and social life; with research of materials and

\footnotetext{
${ }^{1}$ Article derived from the doctoral thesis of the first author, under the supervision of the second, defended in 2014, in the Program of Postgraduate Studies in Education: Psychology of Education of the Pontifícia Universidade Católica de São Paulo. Rua Francisco Marengo, 111, Tatuapé, São Paulo-SP, Brazil. CEP 03.313-000. Support: Coordination for the Improvement of Higher Education Personnel - CAPES.

Correspondence address: Marcelo de Abreu César. Pontifícia Universidade Católica de São Paulo. Rua Monte Alegre, 984, Perdizes, São Paulo-SP, Brazil. CEP 05.014-901. E-mail: marcelocezzar@yahoo.com.br
}

substances, develops scientific-technological knowledge with contributions that imply in economic, social and political reach.At school, although it is expected that the student will acquire knowledge that allows him or her to recognize the occurrence of chemical phenomena present in everyday life, and can act in a more adequate way before them, the System of School Performance Evaluation of the State of São Paulo - SARESP (Secretaria da Educação do Estado de São Paulo, 2014) shows that most of the students in the third year are in the Below Basic and Basic performance levels, showing that their education is 
precarious. The situation is critical, requiring the search for solutions or proposals that make the teaching of Chemistry in high school more efficient.

Behavior analysts have conducted research on the teaching of knowledge and skills; part of this research has been based on the stimulus equivalence model. The work referenced from equivalence studies was conducted by Murray Sidman in 1971. He verified the acquisition of reading by an individual with severe cognitive impairment. The studies of this researcher would lead to the later implementation of a research area referred to as stimulus equivalence.

Sidman (1971) used the matching-to-sample procedure (MTS). The participant, who had already received institutional treatment aimed at his or her needs, was able to name figures and identify them from the dictation of their names. Sidman taught the relation between spoken word (A) and printed word (C). When evaluating the effect of teaching, it was verified that there was an emergence of word reading ( $\mathrm{CD}$ relation) and reading comprehension $(\mathrm{BC}$ and $\mathrm{CB}$ relations). In other words, the author taught one relation and new relations not taught have emerged. Sidman demonstrated the emergence of new behaviors.

Sidman and Tailby (1982) proposed the stimulus equivalence model, which describes a network produced from the teaching of some conditional relations. It is evidenced that there is equivalence between stimuli if relations emerge without direct training: reflexivity (A relates to $\mathrm{A}$ ), symmetry (if $\mathrm{A}$ relates to $\mathrm{B}$, then $\mathrm{B}$ relates to $\mathrm{A}$ ) and transitivity (if $\mathrm{AB}$ and $\mathrm{BC}$, then $\mathrm{AC}$, that is, given the validity of the $\mathrm{AB}$ and $\mathrm{BC}$ relations, the $\mathrm{AC}$ and $\mathrm{CA}$ relations are also valid). In short, the equivalence between stimuli will be proven if these properties are present, meaning that the stimuli have become equivalent, exerting similar control over the individual's response. Studies based on the stimulus equivalence modelhave contributed to education. These studies have demonstrated that different repertoires can be taught with a high degree of precision.

In Brazil, the stimulus equivalence model has been widely used to investigate the teaching of academic abilities, such as reading (César \& Moroz, 2015; Leite \& Hübner, 2009; Machado \& Haydu, 2012; Medeiros, 2011; Ponciano \& Moroz, 2012; Reis, Souza \& De Rose, 2009; Zanco \& Moroz, 2015), Mathematics (Henklain \& Carmo, 2013; Dalto \& Haydu, 2015; Lorena, Castro-Caneguim,\& Carmo, 2013), Music (Hanna, Batitucci, \& Natalino-Rangel, 2016; Salvatori, Silva, Belem, Modenesi, \& Debert, 2011), among others. Most of the studies presented intervention in the researcher-participant format, although part of them worked in a collective context, with intervention in the researchergroup format, like César and Moroz (2015), Machado and Haydu (2012) and Medeiros (2011).

As highlighted by Fields et al. (2009) "The procedural variables that lead to the formation of equivalence classes in the laboratory environment are already well documented" (p. 576). However, according to the authors, it is still necessary to demonstrate the possibility of using procedures based on equivalence for the teaching of more complex contents; in this direction, statistical teaching for university students was identified (Albright, Reeve, Reeve, \& Kisamore, 2015; Fields et al., 2009) and neuroanatomy (Fienup, Mylan, Brodsky, \& Pytte, 2016).

The field of Chemistry, however, is little studied, both in Brazil and abroad; it was located the study of Ferro (1993), which had as one of the objectives to teach the concepts of metals and nonmetals. According to the author, the stimulus equivalence model can be used in the teaching of Chemistry, which can be analyzed as a network of interrelated repertoires and acquired through equivalence relations.

Ferro (1993) used the equivalence model as a reference to teach those concepts. The author taught conditional discriminations, using name (metals $\mathrm{x}$ nonmetals), characteristics (solids at room temperature, good conductors $\mathrm{x}$ liquids at room temperature, bad conductors) and representative elements (Alkaline, Alkaline-earth, Earthy elements and Transition x Halogens, Amphigens, Carbon group and Pnictogen). After teaching, he verified the emergence of not explicitly taught relations, producing classes of equivalent stimuli. The work of Ferro is the closest to the present study.

Considering the importance of proposing productive alternatives for the teaching of Chemistry to students who are attending high school, the present study aimed to verify the effects of a procedure, elaborated based on the stimulus equivalence model, to teach the participants to naming 10 chemical elements, from their symbolic representations and their respective numbers and atomic models.

\section{Method}

The present experimental study was designed with phases of test (initial and final) and two of intervention, namely: Pre-Test - Teaching ${ }^{\text {st }}$ Step - Teaching ${ }^{2 n d}$ Step Post-Test.

\section{Participants}

Eight students - aged between 15 and 17 years old, seven female students who attended regular classes in the second year of the high school of a state public school in the Metropolitan Region of Mogi das Cruzes (P3, P4, P10, P11, P12, P15, P16 and P18).

\section{Instruments}

MestreLibras Software (Elias \& Goyos, 2010). Intended for teachers and other educators, it can assist in teaching academic skills. It allows to introduce sounds and images, making possible the use of the matching to sample (MTS) procedure and constructed response matching to sample (CRMTS) procedure, with randomization of the choices and record of student performance. There are consequences for the hits (having chosen to animate a coin by entering a 
piggy bank); for the wrong answers, the screen dims for a few seconds. The software generates a descriptive report of the participant's performance, identifying correct and incorrect choices, in absolute number and percentage; it also presents the number of trials and the time used to perform the activity.

Stimuli. The representative stimuli of ten chemical elements used in the teaching procedure and in the tests were visual. They are: (A) Printed Name: Carbon, Hydrogen, Oxygen, Nitrogen, Sulfur, Fluorine, Chlorine, Bromine, Iodine, Astatine; (B) symbol: C, H, O, N, S, F, Cl, Br, I, At; (C) atomic number: $6,1,8,7,16,9,17,35,53,85$; (E) atomic model: image of each atomic model corresponding to the chemical elements used. Examples of stimuli are shown in Figure 1.

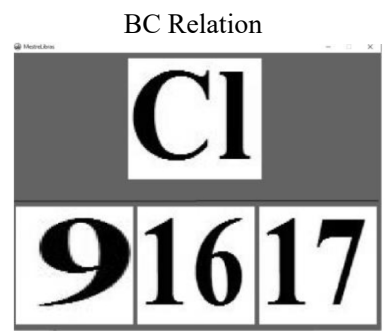

CE Relation

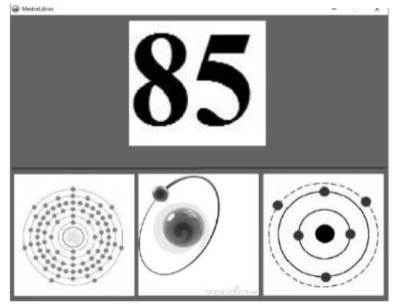

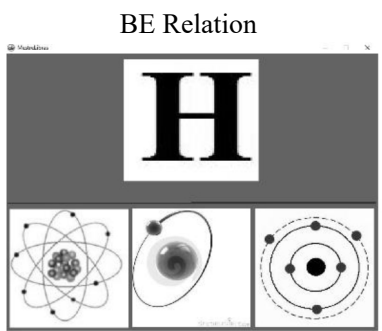

EB Relation

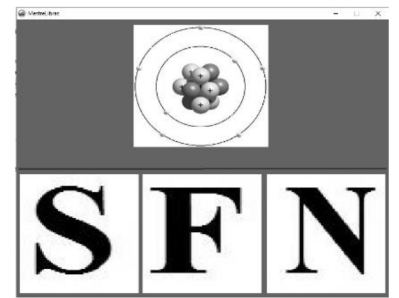

Figure 1.Examples of stimuli used in teaching (BC and BE) and relation test (EC and $\mathrm{EB})$.

Microcomputers, printers, individual headsets were used in the computer room; the microcomputers were arranged in four rows, with five computers side by side.

\section{Procedure}

Data collection. Held in outside classes' hours (extra shift). The procedure consisted of: (1) Evaluation of the initial repertoire (Pre-Test). (2) Teaching of chemical elements, in two steps: ${ }^{\text {st }}$ Step Intervention - Teaching of two relations $(\mathrm{AB}$ and $\mathrm{BC})$ and test of the relations $\mathrm{BA}, \mathrm{CB}, \mathrm{AC}$, $\mathrm{CA}$ and naming the chemical element from the symbol (BD relation) and from the atomic number (CD relation); $2{ }^{\text {nd }}$ Step Intervention - Teaching of the $\mathrm{BE}$ relation and emergency test of the EB, AE, EA, CE, EC relations and the naming of the chemical element from the atomic model (ED relation).

\section{(3) Evaluation of the final repertoire (Post-Test).}

Evaluation of the initial repertoire (Pre-Test). The instructions were provided by the researcher; the activities were presented on the computer, and the participant's performance was recorded automatically. In the Pre-Test, as in the other tests performed, no consequences were released. The Pre-test was performed individually in a single session of a maximum of 50 minutes.

To evaluate the repertoire on the chemical elements, both selection responses (relations between name, symbol, atomic number and atomic model of the 10 chemical elements) as well as naming responses of the 10 chemical elements (from the symbol, the atomic number and the atomic model) were solicited. The chemical elements were: Carbon, Hydrogen, Oxygen, Nitrogen, Sulfur, Fluorine, Chlorine, Bromine, Iodine and Astatine.

For the evaluation of the initial repertoire of chemical elements, 12 relations $(\mathrm{AC}, \mathrm{CA}, \mathrm{AB}, \mathrm{BA}, \mathrm{BC}, \mathrm{CB}, \mathrm{BE}, \mathrm{EB}$, $\mathrm{AE}, \mathrm{EA}, \mathrm{CE}, \mathrm{EC})$ between name (A), symbol (B), atomic number (C) and atomic model (E) of the 10 chemical elements were tested, each with five trials; was also evaluated the naming of the chemical element, from the symbol (BD), the atomic number (CD) and the atomic model (ED), with 10 trialsper relation. In all, there were 15 relations making a total of 90 evaluation trials.

Teaching and test of emergent relations. Each student was allocated in a computer, in which he or she do the activities.. During the intervention, the participants were in a collective context, although they performed activities at their own pace. The matching to sample (MTS) procedure was used. Three weekly sessions were held, with a maximum duration of 40 minutes, in the two steps.

In the $1{ }^{\text {st }}$ Step, 10 teaching blocks were conducted, each with three chemical elements: carbon-hydrogen-oxygen (Block 1); hydrogen-oxygen-nitrogen (Block 2); oxygennitrogen-sulfur (Block 3); nitrogen-sulfur-fluorine (Block 4); sulfur-fluorine-chlorine (Block 5); fluorine-chlorinebromine (Block 6); chlorine-bromine-iodine (Block 7); bromine-iodine-astatine (Block 8); iodine-astatine-carbon (Block 9); astatine-carbon-hydrogen (Block 10). In each block, AB (chemical element name-chemical element symbol) and BC (chemical element symbol-atomic number of the chemical element) were taught. There were 12 trials per teaching relation, totaling 24 trials per block. The performance criterion was $\geq 90 \%$ of hits (one error), per relation taught; if not achieved, the participant was submitted again to the teaching. Once the criterion was reached in the block, the test of emergent relations was applied.

In each block, the emergent relations $\mathrm{BA}, \mathrm{CB}, \mathrm{AC}, \mathrm{CA}, \mathrm{BD}$ and $\mathrm{CD}$ were tested. There were 12 trials per relation, totaling 72 per block. In the BD and CD test, only the symbol or the atomic number was presented, and the participant was asked to give the name of the corresponding chemical element. The researcher recorded the participant's response. In the test of emergent relations, the criterion of performance was also $90 \%$ of hits, at least. The participant remade the trials of the teaching until reaching the criterion, condition to move to a new step.

In the $2^{\text {nd }}$ Step, the relation BE (symbol-atomic model) was taught, integrating the atomic model to one of the elements of the relations previously taught, in this case, symbol (B). Four blocks were conducted: carbon-hydrogen-oxygen (Block 1); nitrogen-sulfur-fluorine (Block 2); chlorine-bromine-iodine 
(Block 3); astatine-carbon-hydrogen (Block 4). There were 18 trialsper block, making 72 trials. The performance criteria and procedure were like those in $1^{\text {th }}$ Step.

At each block, the emergence of EB, AE, EA, CE, EC and ED relations was tested, with 12 trials per relation, totaling 72 trials tested. Again, the performance criterion and procedure were like those in $1^{\text {th }}$ Step. Figure 2 shows the teaching (filled lines) and tested (dotted lines) relations, indicating the integration of the atomic model $(\mathrm{E})$ to the equivalence class previously formed (square).

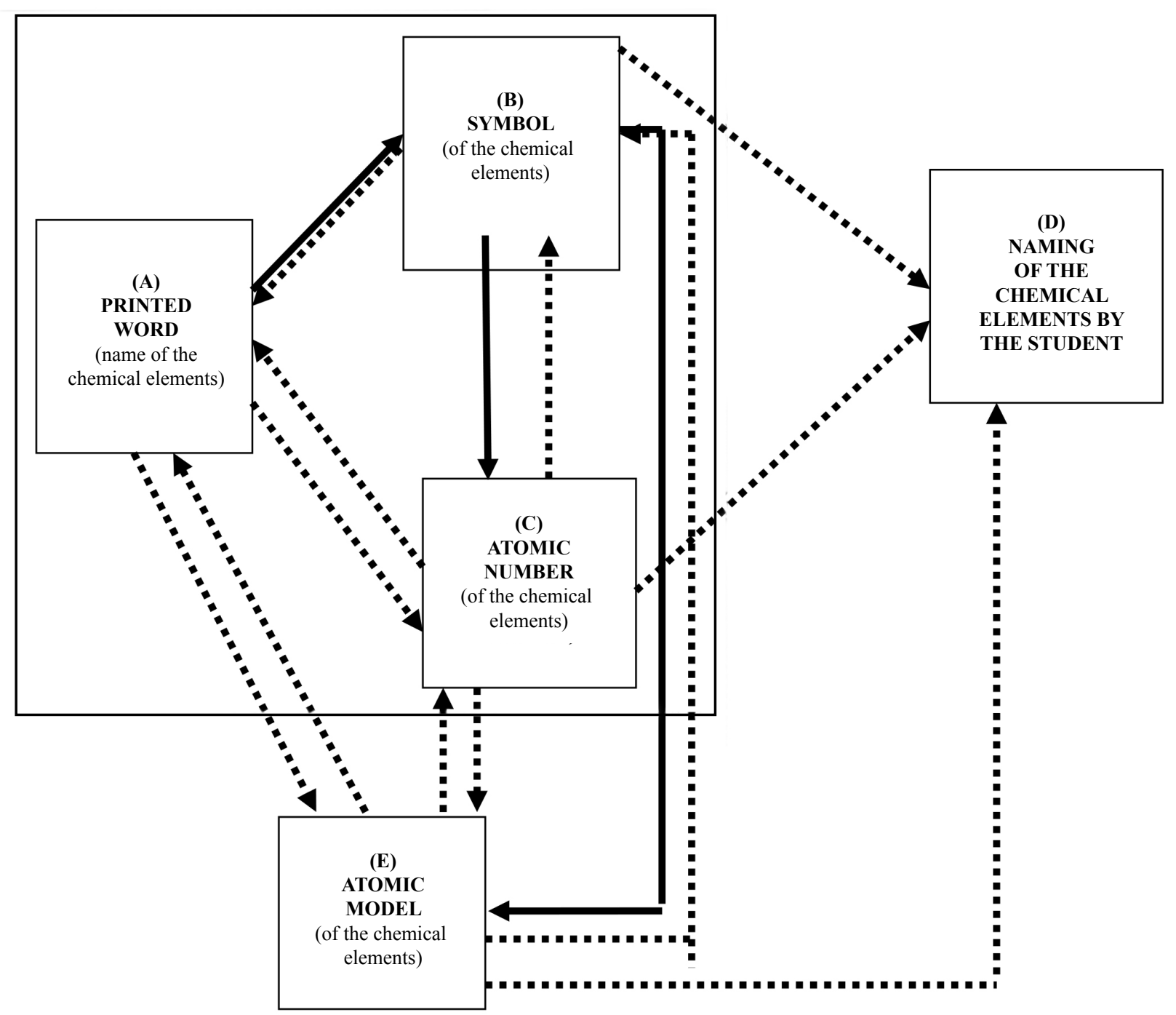

Figure 2. Diagram of relations taught (full lines) and tested (dotted lines). Based on De Rose diagram (2005).

Evaluation of the final repertoire (Post-Test). Once the two intervention steps were completed, the final repertoire (Post-Test) on chemical elements was evaluated. For this purpose, the same itens and procedures of the initial repertoire evaluation (Pre-Test) were reapplied. In Figure 3, the diagram of the experimental conditions of the study is presented.
Data analysis. The performance reports generated by the MestreLibras software were used. The average percentage of hits was obtained by relation taught and tested. The participants' performances were analyzed by focusing on the selection responses (relations $\mathrm{AB}, \mathrm{AC}, \mathrm{BC}, \mathrm{AE}, \mathrm{BE}$, $\mathrm{CE}, \mathrm{BA}, \mathrm{CA}, \mathrm{CB}, \mathrm{EA}, \mathrm{EB}, \mathrm{EC})$ and the naming of chemical elements ( $\mathrm{ED}, \mathrm{BD}$ and $\mathrm{CD}$ relations). 


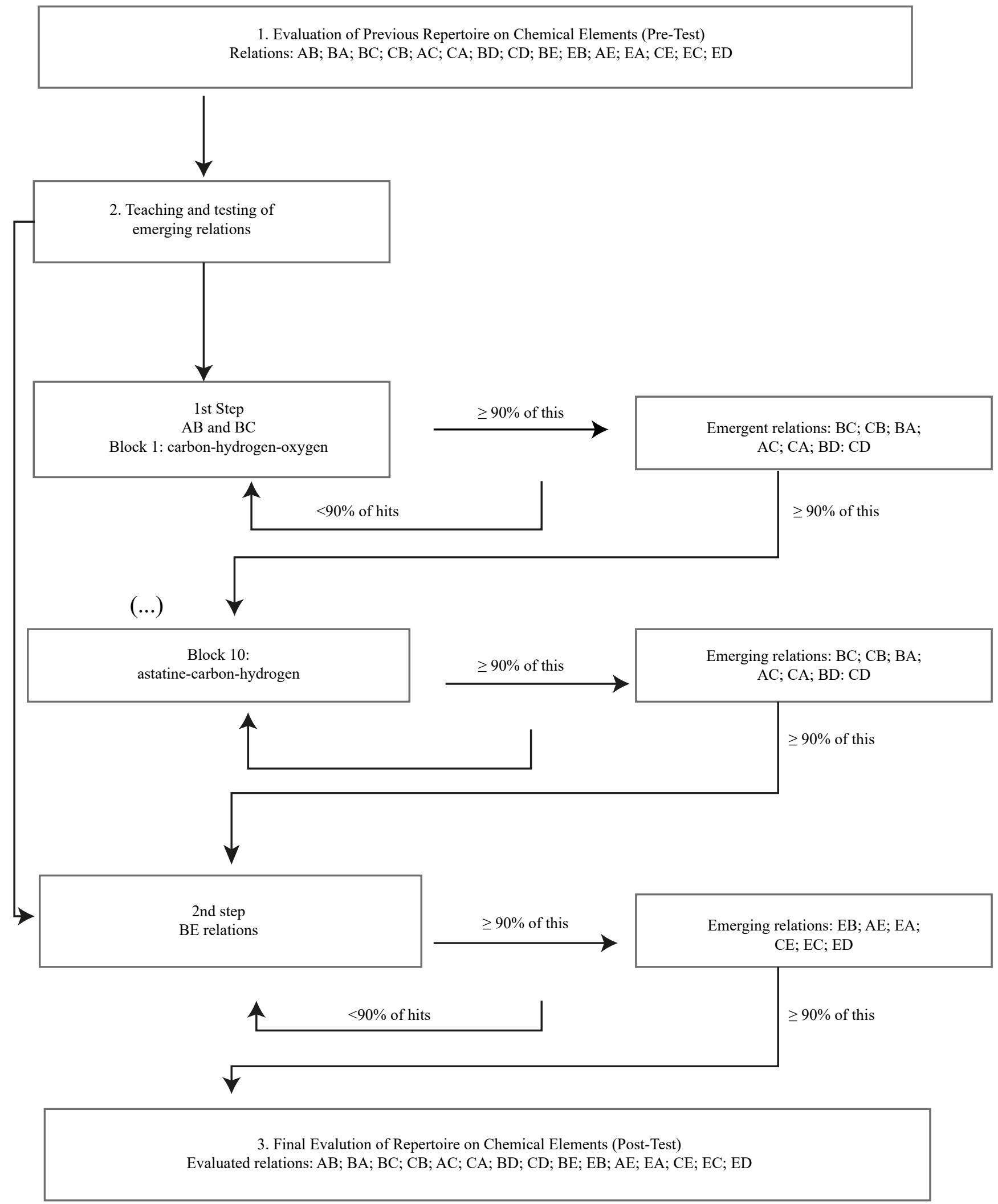

Figure 3. Diagram representative of the experimental design (Pre-Test, Teaching and test of emergent relations and Post-Test), with specification of the relations taught and tested 


\section{Ethical Considerations}

The ethical requirements were fulfilled, in accordance with the Resolution of the National Health Council Resolution CNS / MS No. 196/96. Participants were informed that this was a research on teaching concepts of Chemistry, and participation was optional. The Free and Informed Consent Form was signed by the student's supervisor. The Research Ethics Committee of the Pontíficia Universidade Católica de São Paulo approved this research under the number of Opinion740.195 and CAAE 04684813.7.0000.5482.

\section{Results}

The performance of the participants in the different steps of the procedure will be presented below. Table 1 presents the percentage of participants' hits in the relations evaluated in the Pre-test and Post-test.

Table 1

Percentage of Hits, per Participant, in the Pre-Test and Post-Test

\begin{tabular}{|c|c|c|c|c|c|c|c|c|c|c|c|c|c|c|c|c|}
\hline \multirow{3}{*}{ Participants } & \multicolumn{16}{|c|}{ RELATIONS } \\
\hline & \multicolumn{2}{|c|}{$\mathrm{AB}$} & \multicolumn{2}{|c|}{ BA } & \multicolumn{2}{|c|}{$\mathrm{BC}$} & \multicolumn{2}{|c|}{$\mathrm{CE}$} & \multicolumn{2}{|c|}{$\mathrm{AC}$} & \multicolumn{2}{|c|}{$\mathrm{CA}$} & \multicolumn{2}{|c|}{$\mathrm{BD}$} & \multicolumn{2}{|c|}{$\mathrm{CD}$} \\
\hline & Pre & Post & Pre & Post & Pre & Post & Pre & Post & Pre & Post & Pre & Post & Pre & Post & Pre & Post \\
\hline P3 & 80 & 100 & 80 & 100 & 20 & 100 & 80 & 100 & 0 & 100 & 80 & 100 & 20 & 100 & 10 & 90 \\
\hline $\mathrm{P} 4$ & 80 & 100 & 80 & 100 & 20 & 100 & 60 & 100 & 60 & 100 & 80 & 100 & 20 & 100 & 0 & 60 \\
\hline $\mathrm{P} 10$ & 100 & 100 & 80 & 100 & 60 & 100 & 80 & 100 & 10 & 100 & 60 & 100 & 50 & 100 & 10 & 90 \\
\hline P11 & 100 & 100 & 80 & 100 & 60 & 100 & 80 & 100 & 20 & 100 & 60 & 100 & 60 & 100 & 10 & 90 \\
\hline $\mathrm{P} 12$ & 60 & 100 & 80 & 100 & 20 & 80 & 10 & 100 & 0 & 80 & 80 & 100 & 60 & 100 & 0 & 80 \\
\hline $\mathrm{P} 15$ & 80 & 100 & 80 & 100 & 10 & 100 & 20 & 100 & 10 & 100 & 60 & 100 & 20 & 100 & 10 & 80 \\
\hline P16 & 60 & 100 & 60 & 100 & 0 & 100 & 20 & 80 & 20 & 100 & 20 & 100 & 50 & 100 & 0 & 80 \\
\hline P18 & 80 & 100 & 60 & 100 & 0 & 100 & 20 & 100 & 0 & 100 & 10 & 100 & 44 & 100 & 0 & 100 \\
\hline \multirow{2}{*}{ Participants } & \multicolumn{2}{|c|}{$\mathrm{BE}$} & \multicolumn{2}{|c|}{ EB } & \multicolumn{2}{|c|}{$\mathrm{AE}$} & \multicolumn{2}{|c|}{ EA } & \multicolumn{2}{|c|}{$\mathrm{CE}$} & \multicolumn{2}{|c|}{$\mathrm{EC}$} & \multicolumn{2}{|c|}{ ED } & & \\
\hline & Pre & Post & Pre & Post & Pre & Post & Pre & Post & Pre & Post & Pre & Post & Pre & Post & & \\
\hline P3 & 100 & 100 & 60 & 100 & 60 & 100 & 60 & 100 & 80 & 100 & 100 & 100 & 10 & 80 & & \\
\hline P4 & 100 & 100 & 80 & 100 & 20 & 100 & 80 & 100 & 10 & 100 & 80 & 100 & 0 & 90 & & \\
\hline $\mathrm{P} 10$ & 80 & 100 & 20 & 100 & 20 & 100 & 80 & 100 & 10 & 100 & 80 & 100 & 0 & 100 & & \\
\hline P11 & 20 & 100 & 80 & 100 & 10 & 100 & 60 & 100 & 60 & 100 & 100 & 100 & 20 & 100 & & \\
\hline P12 & 20 & 100 & 80 & 100 & 10 & 100 & 60 & 100 & 20 & 80 & 20 & 100 & 0 & 50 & & \\
\hline $\mathrm{P} 15$ & 10 & 100 & 10 & 100 & 10 & 100 & 10 & 100 & 10 & 100 & 10 & 100 & 0 & 90 & & \\
\hline P16 & 20 & 100 & 10 & 80 & 80 & 100 & 10 & 100 & 20 & 80 & 20 & 100 & 0 & 90 & & \\
\hline P18 & 30 & 100 & 20 & 100 & 10 & 100 & 20 & 100 & 0 & 100 & 10 & 100 & 0 & 100 & & \\
\hline
\end{tabular}

\section{Performance of Participants in the Initial Evaluation (Pre-Test)}

Considering the relations evaluated between the name of the chemical elements and the respective symbol, atomic number and atomic model (from $\mathrm{AB}$ to $\mathrm{EC}$ ), the worst performances were those of P11, P12, P15, P16 and P18, because in a maximum five of 12 relations evaluatedthey presented between $80 \%$ and $100 \%$ of hits. The best performance was of P3, P4 and P10, since they reached between $80 \%$ and $100 \%$ of hits in seven and six, respectively, of the relations evaluated, a fact that indicates a certain level of knowledge of chemistry.

As for the naming of the chemical elements, from the symbol, atomic number and atomic model (BD, CD, ED relations) the results were clearly worse.Only when the symbols were presented (BD relation), there were $50 \%$ or $60 \%$ of hits, for P11, P12, P10 and P16. Already in the naming of the chemical elements from the atomic number (CD relation) and atomic model (ED relation), the participants practically did not present hits. These results reveal that only a few participants named part of the chemical elements as they visualized their symbols; however, they did not name them from their respective numbers and atomic models.

\section{Performance of Participants in the First Step}

During the teaching of $\mathrm{AB}$ and $\mathrm{BC}$ relations ( $1^{\text {th }}$ Step), participants, except for $\mathrm{P} 4$ and $\mathrm{P} 16$, repeated the trials of $\mathrm{BC}$ relation to achieve the performance criterion ( $\geq 90 \%$ of hits). In the emergency test, all participants, except P15 (who had about $90 \%$ of hits in three of the six evaluated relations) and 
P18 (who had $94 \%$ of hits in a single relation evaluated), all presented a maximum percentage of hits, or close to it. From the teaching of two relations, six relation not directly taught (stimulus-stimulus: $\mathrm{CB}, \mathrm{BA}, \mathrm{AC}, \mathrm{CA}$, stimulus-response: $\mathrm{BD}, \mathrm{CD})$ emerged, including naming the chemical element, both from the symbol and from the atomic number. The symmetrical and transitive relations emerged, indicating that the stimuli of sets $\mathrm{A}, \mathrm{B}$, and $\mathrm{C}$ became equivalent.

\section{Performance of Participants in the Second Step}

The $\mathrm{BE}$ relation was integrated into the equivalence class formed by three-member stimuli, and the emergence of EB, AE, EA, CE, EC and ED (naming of the chemical element from the atomic model) was tested.

The results obtained during the teaching of $\mathrm{BE}$, as presented in Table 2, show that except for P10 and P18 that presented $100 \%$ of hits, the other participants repeated the teaching trials to obtain the criterion of performance. In the test of emergent relations (EB, AE, EA, CE, EC and ED), the performance was excellent, since all presented above $90 \%$ of hits in all relations tested, and six of the eight participants presented $95 \%$ of hits at least. It's worth noting the naming of the chemical element from the atomic model (ED relation), with maximum percentage of hits by all participants.

The results showed that from a single relation taught, six new relations emerged. With the integration of a new element (E) into the class of equivalent stimuli (A, B, C), new relations emerged between the integrated element and the other elements of the equivalence class previously formed.

\section{Performance of Participants in the Final Evaluation (Post-Test)}

At the end of the $2^{\text {nd }}$ Step, the eight participants were again submitted to the evaluation of the repertoire of chemical elements (reapplication of the Pre-Test).

As shown in Table 1, in the Post-Test, in the relations between chemical name, symbol, atomic number $(\mathrm{AB}, \mathrm{BA}$, $\mathrm{BC}, \mathrm{CB}, \mathrm{AC}, \mathrm{CA}, \mathrm{BE}, \mathrm{EB}, \mathrm{AE}, \mathrm{EA}, \mathrm{CE}, \mathrm{EC})$, the participants matched all attempts, except for $\mathrm{P} 12$ in the $\mathrm{BC}, \mathrm{AC}$ and $\mathrm{CE}$ relations and $\mathrm{P} 16$ in the $\mathrm{CB}, \mathrm{EB}, \mathrm{CE}$ relations, both with $80 \%$ of hits. The improvement in performance, in the relations to which the participant chose the alternative, was evident. As for the naming of the chemical elements $(B D, C D$ and ED), except for $\mathrm{P} 4$, in the naming from the atomic number (CD) and P12, in the naming from the atomic model (ED), respectively with $60 \%$ and $50 \%$ of hits, the others presented between $80 \%$ and $100 \%$ of hits.

Comparing the data of the Pre-Test and Post-Test, there was an evident improvement in the percentages of hits of all the participants, highlighting the relations in which the atomic model was included, and for the naming of the chemical elements, from the symbol, the atomic number and the atomic model.

\section{Discussion}

The objective of the present study was to teach the participants to naming the chemical elements, from their symbolic representations and their numbers and atomic models. For this, a teaching program of conditional discriminations was proposed, based on the stimulus equivalence model, applied with the software MestreLibras in a collective context.

In the initial repertoire of the participants, students of the second year of high school, the results showed that, in the 12 relations between name $(\mathrm{A})$, symbol (B), atomic number (C) and atomic model (E), the best performance occurred in the relation between name and symbol ( $\mathrm{BB}$ and $\mathrm{BA})$. In the relation in which the response of naming of the chemical element was evaluated, either from the symbol (BD), or from the atomic number (CD) or even from the atomic model (ED), it was verified that the best performance occurred in naming the chemical element from the symbol (BD), although in part of the chemical elements and by only some of the participants. The evaluation of the previous repertoire allowed to verify that participants who correctly selected the alternatives in the relation between the name and symbol of the chemical elements (AB and BA) could not oralize the chemical elements from their symbolic representation (BD). It became clear, therefore, that they were different repertoires. The results also indicated that the participants did not have the repertoire of Chemistry, target of the present study.

As for the teaching procedure (Steps1 and 2), the data indicated that it was adequate for the participants, since they did the teaching activities according to their own learning rhythm, reaching the expected performance level spending between 2 hours and 4 hours of activities, which does not even correspond to a normal period of classroom activities, since high school have, on average, 5 hours and 20 minutes a day. It was evident the economy of time in carrying out the activities (teaching and testing of emergent relations). This is an important result, since it shows that it is possible to teach and obtain excellence in performance in a short time, provided that the contingencies of teaching are planned, as highlighted by Skinner (1968/1972). It is also worth noting that such excellence in repertoire differs dramatically from what has been detected in the SARESP systematic evaluations carried out in the State of São Paulo (Secretaria da Educação do Estado de São Paulo, 2014).

Regarding the context of the intervention (Steps 1 and 2 ), it is important to highlight that the teaching was carried out in a collective situation, in the researcher-group format. Although the number of participants was reduced, compared to the number of students in a regular classroom in which the teacher interacts with an average of 40 to 45 students per class, the context of the present study approached the educational condition of the classroom. The feasibility of using procedures, based on the equivalence model, in a collective context, has been demonstrated,as happened in the studies by César and Moroz (2015), Fernandes and Moroz (2011), Machado and Haydu (2012) and Medeiros (2011). 
In addition, it was possible to use procedures to teach more complex repertoires, as suggested by Fields et al.(2009).

Unlike the elementary school students who require the constant assistance of the teacher, the high school students already have a level of autonomy that favors their interaction with technological resources. In the case of programming in the MestreLibras software (Elias \&Goyos, 2010), for example, they accessed the tasks and the performance report, evaluated their own performances on the tasks independently of the conference by the researcher, selected the tasks sequentially independently of the researcher, among other actions. Therefore, it is feasible to use equipment available in schools, such as computers and software, to teach the disciplines that make up the school program, opening other possibilities for teaching. To do this, the teacher must to know how to program the teaching, as indicated by Skinner (1968/1972), and to do so, he can take advantage of the students' computer skills, establishing new contingencies for the teaching-learning process in the educational context.

The emergence test of the $\mathrm{CB}, \mathrm{BA}, \mathrm{AC}, \mathrm{CA}$ relations was applied after teaching $\mathrm{AB}$ (printed name-symbol) and $\mathrm{BC}$ (printed name-symbol) relations. The results showed the emergence of symmetrical and transitive relations, as occurred in the study of Ferro (1993), without having been directly taught. This result is in line with what was proposed by the stimulus equivalence model (Sidman\&Tailby, 1982) and is confirmed in applied studies, as highlighted by Fields et al. (2009). The emergence of new repertoires occurred, but not only the receptive, that is, by selection response of the stimulus corresponding to the model. It was verified that the orally naming of the chemical elements emerged from the symbol (BD) and the atomic number (CD), in the first step of the intervention. The tests indicated that equivalence classes were formed by three-member stimuli: printed name, symbol and atomic number of the chemical element.

As described, in the second step of teaching the stimulus $\mathrm{E}$ (atomic model) was integrated to one of the components of the equivalence class, in this case the stimulus B (symbol). The BE relation (symbol-atomic model) was taught, and then the emergence test of the EB, AE, EA, CE, EC, ED relations was applied. The results showed again the emergence of all relations, without explicit teaching. With the teaching of a single relation containing the atomic model, there was the emergence of a selection repertoire (relations EB, AE, EA, $\mathrm{CE}, \mathrm{EC}$ ), and productive repertoire, such as the naming the chemical element from the atomic model (ED), without having been directly taught. The emergence of this last relation is important, since it indicates that the integration of a new stimulus (E: atomic model) to the class of equivalent stimuli allowing the amplification of the emergent relations.

According to the stimulus equivalence model, it is not necessary to teach explicitly all relations when a new element is integrated to aequivalence class. It is enough integrate the new member to one member of the equivalence class; thus, the teaching of only one relation is enough for the others to emerge. As highlighted by De Rose (2005):
These relations are in principle independent but can integrate as some of them are learned. When this integration occurs, new relations not explicitly taught can emerge: the teaching of some of them results in transference to new relations, with little or no explicit teaching of these new relations (p. 42).

As pointed out by Arntzen (2010), the works of Sidman (1971) generated great impact, not only on basic research, but also on applied research, passing the researchers to focus different skills with different types of participants. Studies based on the stimulus equivalence model permit understand how behaviors appear that were not directly trained, fact evidenced in the present work.

In short, post-teaching evaluation indicated clear difference in the students' repertoire, comparing to what was presented before teaching, allowing to conclude that the participants learned to relate the atomic model, symbols and atomic numbers to the name of the chemical elements. The evident difference presented in the Post-Test indicates that the proposed teaching program was effective in promoting the improvement of participants' repertoire. It demonstrates the feasibility of using procedures based on the stimulus equivalence model to teach, in an efficient way, complex repertoires, such as those on the field of Chemistry.

Finally, reference should be made to the fact that, in the present study, no control group was used, making it impossible to compare the results obtained by using technology derived from the equivalence of stimuli and those obtained by other teaching procedures. Although this absence does not invalidate the conclusion that the teaching procedure adopted had positive effects, such a comparison could provide data that would allow us to present new arguments indicating the effectiveness of this technology in the education area, especially in the teaching of Chemistry.

\section{References}

Albright, L., Reeve, K. F., Reeve, S. A., \& Kisamore, A. N. (2015). Teaching statistical variability with equivalencebased instruction. Journal of Applied Behavior Analysis, 48(4), 883-894. doi:10.1002/jaba.249

Arntzen, E. (2010). Comments on Sidman's remarks.Behavior and Philosophy, 38, 173-177.doi:10.2307/41806307

César, M. A., \& Moroz, M. (2015). Leitura para alunos do Ensino Fundamental - Ensino de discriminações condicionais em contexto coletivo com uso de software educativo.[Reading for primary school students Teaching of conditional discriminations in a collective context using educational software]. In V. B. Haydu\& S. R. Souza (Orgs.),Análise do comportamento aplicada a diferentes contextos (pp. 203-235). Londrina, PR: Eduel. 
Dalto, J. O., \& Haydu, V. B. (2015). Equivalência de estímulos no ensino de funções matemáticas de primeiro grau no Ensino Fundamental [Equivalence of stimulus in the teaching of first-order mathematical functions in elementary school]. Perspectivas em Análise do Comportamento, 6(2), 132-146. doi:10.18761/pac.2015.022

De Rose, J. C. (2005). Análise comportamental da aprendizagem de leitura e escrita [Behavior analysis of reading and writing learning]. Revista Brasileira de Análise do Comportamento/ Brazilian Journal of Behavior Analysis, 1(1), 29-50. doi:10.18542/ rebac.v1i1.676

Elias, N. C., \& Goyos, C. (2010). MestreLibras no ensino de sinais: Tarefas informatizadas de escolha de acordo com o modelo e equivalência de estímulos [MestreLibras the signa lschool: Computerized tasks of choice according to the model and stimulus equivalence]. In E. G. Mendes \& M. A. Almeida (Eds.), Das margens ao centro: Perspectivas para as politicas e práticas educacionais no contexto da educação especial inclusiva [Margins to center: Perspectives for educational policies and practices in the context of inclusive special education] (pp. 223-234). Araraquara, SP: Junqueira e Marin.

Fernandes, M. A. P., \& Moroz, M. (2011). Ensino de leitura para alunos do ensino fundamental - uma proposta com base na análise do comportamento [Reading teaching for students in elementary school - proposal based on the behavior analysis]. Psicologia da Educação, (32), 47-68. Retrieved from http://pepsic.bvsalud.org/pdf/psie/n32/n32a04.pdf

Ferro, R. (1993). Formación de reglas y formación de equivalencias en un estúdio aplicado.(Proyecto de iniciación a la investigación). Universidad de Granada, Granada, España.

Fields, L., Travis, R., Roy, D., Yadlovker, E., Aguiar-Rocha, L.,\& Sturmey, P. (2009). Equivalence class formation: Amethod for teaching statistical interactions. Journal of Applied Behavior Analysis, 42(3), 575-593. doi:10.1901/jaba.2009.42-575

Fienup, D. M., Mylan, S. E., Brodsky, J., \& Pytte, C. (2016). From the laboratory to the classroom: The effects of the equivalencebased instruction on neuroanatomy competence. Journal of Behavioral Education, 25(2), 143-165. doi:10.1007/s10864015-9241-0

Hanna, E. S., Batitucci, J. S. L., \& Natalino-Rangel, P. C. (2016). Paradigma de equivalência de estímulos norteando o ensino de rudimentos de leitura musical [Stimulus equivalence paradigm a guiding the teaching of Reading music rudiments]. Acta Comportamentalia, 24(1), 29-46. Retrieved from http://www.revistas.unam. mx/index.php/ acom/ article/ view/ 54711/48627

Henklain, M. H. O.,\& Carmo, J. S. (2013). Equivalência de estímulos e redução dedificuldades na solução de problemas de adição e subtração [Equivalence stimulus and difficulties reduced adding trouble shooting and subtraction]. Psicologia: Teoria e Pesquisa, 29(3), 341350. doi:10.1590/S0102-37722013000300012
Leite, M. K. S., \& Hübner, M. M. C. (2009). Aquisição de leitura recombinativa após treinos e testes de discriminações condicionais entre palavras ditadas e impressas [Acquisition of recombinative reading after trainings and tests with dictated and printed words]. Psicologia: Teoria e Prática, 11(3), 63-81. Retrieved from http://pepsic.bvsalud.org/scielo. php?script=sci_arttext\&pid=S1516-6872009000300007\&ln $\mathrm{g}=\mathrm{pt} \& \mathrm{nrm}=\mathrm{iso} \& \mathrm{tlng}=\mathrm{pt}$

Lorena, A. B., Castro-Caneguim, J. F., \& Carmo, J. S. (2013). Habilidades numéricas básicas:Algumas contribuições da análise do comportamento [Basic numerical skills: Some behavior analysis of contributions]. Estudos de Psicologia (Natal), 18(3), 439-446. doi:10.1590/S1413294X2013000300004

Machado, L. M., \& Haydu, V. B. (2012). Escolha de acordo com o modelo de estímulos: Ensino de leitura de palavras em situação coletiva [Choose according to model and equivalence of stimuli: reading teching of words in collective situation]. Psicologia da Educação, (35), 72-94. Retrieved from http://pepsic.bvsalud.org/scielo. php?script $=$ sci_arttext\&pid=S1414-69752012000200005

Medeiros, J. C. (2011). A discriminação condicional como método para ensinar criançasa ler em situação coletiva de sala de aula [Conditional discrimination as a method to teach children to read in collective situation of the classroom]. Psicologia: Teoria e Prática, 13(2), 3049. Retrieved from http://pepsic.bvsalud.org/scielo. php?script $=$ sci_arttext\&pid=S1516-36872011000200003

Ponciano, V. L. O., \& Moroz, M. (2012). Utilizando frases como unidades de ensino de leitura: Um procedimento baseado na equivalência de estímulos [Using phrases like reading teaching units: A procedure based on stimulus equivalence]. Revista Brasileira de Terapia Comportamental e Cognitiva, 14 (1), 38-56. doi:10.31505/rbtcc.v14i1.492

Reis, T. S., Souza, D. G., \& De Rose, J. C. (2009). Avaliação de um programapara o ensinode leitura e escrita [Evaluation of a program for teaching of reading and writing]. Estudo sem Avaliação Educacional, 20(44), 425-450.doi:10.18222/ eae204420092038

Salvatori, A., Silva, C. S., Belem, I. E. A., Modenesi, R. D.,\& Debert, P. (2011). Matching de identidade com estímulos compostos e o ensino de notas musicais [Identity-matching with compound stimulus and musical notes learning]. Acta Comportamentalia, 20(3), 287-298. Retrieved from http://pepsic.bvsalud.org/scielo.php?script=sci arttext\&pid=S0188-81452012000300003

Secretaria da Educação do Estado de São Paulo. Coordenadoria de Estudos e Normas Pedagógicas. (2014). Sistema de Avaliação do Rendimento Escolar do Estado de São Paulo: SARESP. São Paulo, SP: SEE/CENP. Retrieved from http:// saresp.fde.sp.gov.br/2014/ 
Sidman, M. (1971). Reading and auditory-visual equivalences. Journal of Speech and Hearing Research,14(1), 5-13. doi:10.1044/jshr.1401.05

Sidman, M., \& Tailby, W. (1982). Conditional discrimination vs. matching to sample:An expansion of the testing paradigm. Journal of the Experimental Analysis of Behavior, 37(1), 5-22. doi:10.1901/jeab.1982.37-5

Skinner, B. F. (1972). Tecnologia do ensino [The technology of teaching] (R. Azzi, Trad.).São Paulo, SP: Herder/ Edusp. (Trabalho original publicado em 1968).

Zanco, G., \& Moroz, M. (2015). Ensino de leitura de orações por meio de discriminaçõescondicionais [Prayer reading education through discriminations conditionals]. Psicologia: Teoria e Pesquisa, 31(4), 509-517. doi:10.15900102-37722015042363509517

Marcelo de Abreu César holds a Ph.D. from Pontifícia Universidade Católica de São Paulo, São Paulo-SP, Brazil.

Melania Moroz is a Professor of the Pontifícia Universidade Católica de São Paulo, São Paulo-SP, Brazil.

\section{Authors' Contribution:}

All authors made substantial contributions to the conception and design of this study, to data analysis and interpretation, and to the manuscript revision and approval of the final version. All the authors assume public responsability for content of the manuscript.

Received: Oct. 18, 2016

1st Revision: Dez. 30, 2017

Approved: Apr. 26, 2018

How to cite this article:

César,M.A.,\&Moroz,M.(2018). Teaching chemistrybased on the stimulus equivalence model. Paidéia (Ribeirão Preto), 28, e2838. doi: http://dx.doi.org/10.1590/1982-4327e2838 